\title{
GAMBARAN KADAR HIGH DENSITY LIPOPROTEIN DARAH PADA LAKI-LAKI BERUSIA 40-59 TAHUN DENGAN INDEKS MASSA TUBUH $\geq 23 \mathrm{~kg} / \mathrm{m}^{2}$
}

\author{
${ }^{1}$ Rizky R. Syahrullah \\ ${ }^{2}$ Youla Assa \\ ${ }^{2}$ Murniati Tiho
}

\author{
${ }^{1}$ Kandidat skripsi Fakultas Kedokteran Universitas Sam Ratulangi Manado \\ ${ }^{2}$ Bagian Bikomia Fakultas Kedokteran Universitas Ssam Ratulangi Manado \\ Email: Cindra.karim20@yahoo.com
}

\begin{abstract}
High density lipoprotein (HDL) is a lipoprotein containing apo A-1, associated with other apolipoproteins. One of the HDL functions is as the reversed transporter of cholesterol in order to reduce cholesterol level in peripheral tissues. Low HDL cholesterol level is often related to obesity. High cholesterol level, obesity, and low HDL level are known as risk factors of coronary heart diseases. Overweight subjects have higher probabality for suffering from heart diseases and stroke. This study aimed to elaborate high density lipoprotein (HDL) levels in males aged 40-59 years with body mass index higher than 23 $\mathrm{kg} / \mathrm{m}^{2}$. This study used consecutive sampling method. Total subjects involved in this study were 20 males who lived in Malalayang. The results showed that there were 11 subjects with normal HDL levels and nine subjects (45\%) with low HDL levels $(<45 \mathrm{mg} / \mathrm{dL})$. No subjects had high HDL level. Nineteen subjects (95\%) were classified as obesity and only one subject (5\%) as overweight. Conclusion: Most of the males 40-59 aged with body mass index $\geq 23$ $\mathrm{kg} / \mathrm{m}^{2}$ who lived in Malalayang Manado has normal HDL level.
\end{abstract}

Keywords: males, high density lipoprotein, body mass index

\begin{abstract}
Abstrak: High density lipoprotein (HDL) ialah lipoprotein yang mengandung apoA-I, disamping apolipoprotein lainnya. Salah satu fungsi HDL ialah transpor balik kolesterol untuk menurunkan kadar kolesterol di jaringan perifer. Rendahnya kolesterol HDL sering dikaitkan dengan obesitas. Tingginya kolesterol, obesitas, dan rendahnya kadar HDL merupakan faktor risiko penyakit jantung koroner. Individu dengan berat badan berlebihan berpeluang lebih besar untuk terkena penyakit jantung dan stroke. Penelitian ini bertujuan untuk mengetahui gambaran kadar high density lipoprotein (HDL) pada laki-laki berusia 40-59 tahun dengan indeks massa tubuh $\geq 23 \mathrm{~kg} / \mathrm{m}^{2}$. Metode penelitian yang digunakan ialah consecutive sampling. Subyek penelitian berjumlah 20 orang laki-laki yang berdomisili di Kecamatan Malalayang Manado. Hasil penelitian memperlihatkan 11 subyek (55\%) dengan kadar HDL normal, sembilan subyek (45\%) dengan kadar HDL rendah $(<45 \mathrm{mg} / \mathrm{dL})$; dan tidak ada $(0 \%)$ yang memiliki kadar HDL tinggi $(>60 \mathrm{mg} / \mathrm{dL})$. Terdapat 19 subjek $(95 \%)$ dengan obesitas dan hanya satu subjek (5\%) yang mengalami overweight. Simpulan: Sebagian besar laki-laki berusia 40-59 tahun yang berdomisili di Kecamatan Malalayang Manado dengan indeks massa tubuh $\geq 23 \mathrm{~kg} / \mathrm{m}^{2}$ mempunyai kadar HDL normal.
\end{abstract}

Kata kunci: laki-laki, high density lipoprotein, indeks massa tubuh

Kolesterol merupakan senyawa lemak kompleks yang berada pada setiap sel di dalam tubuh. Kolesterol berfungsi sebagai materi awal untuk pembentukan cairan 
empedu, dinding sel, vitamin dan hormon tertentu, misalnya hormon seks, dan lainlain. ${ }^{1}$

Kolesterol yang terdapat dalam aliran darah berbentuk lipoprotein, dan berfungsi sebagai komponen stabilisasi membran sel dan prekursor garam empedu serta hormon steroid. Prekursor kolesterol diubah menjadi ubikuinon, dolikol, dan di kulit menjadi kolekalsiferol yaitu bentuk aktif vitamin $\mathrm{D}^{2}$

Peningkatan kadar kolesterol dalam darah dikaitkan dengan pembentukan plak aterosklerotik yang dapat menyumbat pembuluh darah, serta memicu serangan jantung dan stroke. Walaupun kadar kolesterol low density lipoprotein (LDL) yang tinggi bersifat aterogenik, kadar kolesterol HDL yang tinggi bersifat protektif karena partikel HDL berperan mengeluarkan kolesterol dari jaringan dan mengembalikannya ke hati. ${ }^{2}$

Obesitas adalah kelebihan jumlah lemak tubuh lebih dari 19\% pada laki-laki dan lebih dari $21 \%$ pada perempuan. ${ }^{3}$ Obesitas berhubungan dengan penyakit jantung koroner terutama karena pengaruhnya pada tekanan darah, kadar kolesterol darah, dan juga penyakit diabetes melitus. ${ }^{4}$

Kolesterol HDL rendah merupakan faktor risiko yang lebih besar untuk penyakit jantung pada pasien obesitas dibandingkan merokok, total kolesterol, tekanan darah, atau jenis kelamin. ${ }^{5}$ Kadar HDL harus meliputi lebih dari $25 \%$ dari kadar kolesterol total yaitu tidak boleh kurang dari $40 \mathrm{mg} / \mathrm{dL}^{6}{ }^{6}$ Rendahnya kadar HDL dapat menyebabkan penyempitan dan pengerasan pembuluh darah, yang dikenal sebagai aterosklerosis. ${ }^{7}$

World Health Organitation (WHO) dan Organisasi Federasi Jantung Sedunia (World Heart Federation) memprediksi penyakit jantung akan menjadi penyebab utama kematian di negara-negara Asia pada tahun 2010. Di tahun 2020 diperkirakan penyakit kardiovaskuler menjadi penyebab kematian 25 orang setiap tahunnya. Oleh karena itu, penyakit jantung koroner (PJK) menjadi penyebab kematian dan kecacatan nomor satu di dunia. ${ }^{8}$

\section{METODE PENELITIAN}

Penelitian ini bersifat deskriptif. Penelitian dilakukan selama satu bulan (Desember 2011) di Kecamatan Malalayang. Pemeriksaan sampel darah dilakukan di laboratorium klinik Prokita, Manado Sulawesi Utara.

Kriteria inklusi dalam penelitian ini yaitu bersedia menjadi responden, berjenis kelamin laki-laki, dan berusia 40-59 tahun. Kriteria eksklusi yaitu peminum alkohol, sedang dalam program diet, atlit, atau sedang dalam pengobatan atau mengonsumsi obat golongan statin.

Sebagai variabel penelitian yaitu kadar kolesterol HDL darah, laki-laki yang berusia 40-59 tahun, serta memiliki indeks massa tubuh $\geq 23 \mathrm{~kg} / \mathrm{m}^{2}$.

\section{HASIL}

\section{Distribusi subjek berdasarkan kelompok usia}

Distribusi subjek berdasarkan kelompok usia memperlihatkan kelompok usia 40-59 tahun sebesar 55\% dan kelompok usia 50-59 tahun sebesar 45\% (Tabel 1).

Tabel 1. Distribusi subjek berdasarkan kelompok usia

\begin{tabular}{lll}
\hline Usia & $\mathbf{n}$ & $\mathbf{\%}$ \\
\hline $40-49$ & 11 & 55 \\
$50-59$ & 9 & 45 \\
\hline Total & 20 & 100 \\
\hline
\end{tabular}

\section{Distribusi subjek berdasarkan hasil pemeriksaan kolesterol HDL}

Distribusi subjek berdasarkan hasil pemeriksaan kolesterol HDL memperlihatkan subyek dengan kadar HDL kurang dari $40 \mathrm{mg} / \mathrm{dL}$ sebanyak sembilan orang (45\%), 40-60 $\mathrm{mg} / \mathrm{dL}$ sebanyak sebelas orang (55\%), sedangkan yang lebih dari 60 $\mathrm{mg} / \mathrm{dL}$ tidak ada (Tabel 2).

\section{BAHASAN}

National Cholesterol Education Program (NCEP) menunjukkan bahwa usia, 
hipertensi, riwayat keluarga yang menderita PJK pada usia muda, diabetes melitus, merokok, peningkatan kolesterol low density lipoprotein (LDL) dan penurunan kolesterol high density lipoprotein(HDL) merupakan faktor risiko independen terhadap PJK. ${ }^{9}$

Tabel 2. Distribusi subjek berdasarkan kadar kolesterol HDL

\begin{tabular}{ccc}
\hline $\begin{array}{c}\text { HDL } \\
(\mathbf{m g} / \mathbf{d L})\end{array}$ & $\mathbf{n}$ & $\%$ \\
\hline$<40$ & 9 & 45 \\
$40-60$ & 11 & 55 \\
$>60$ & 0 & 0 \\
\hline Total & 20 & 100 \\
\hline
\end{tabular}

Kadar kolesterol HDL akan semakin menurun dengan semakin meningkatnya IMT. Hasil yang sama ditunjukkan pada penelitian Lemieux et al. (2000) menyatakan bahwa IMT yang semakin meningkat berhubungan dengan meningkatnya kadar kolesterol dan triasilgliserol (TAG), menurunnya kadar HDL serta meningkatnya kadar kolesterol LDL. ${ }^{9}$ Pada penelitian ini sebagian besar subjek dengan IMT $\geq 23$ $\mathrm{kg} / \mathrm{m}^{2}(55 \%)$ masih mempunyai kadar kolesterol HDL $\geq 40 \mathrm{mg} / \mathrm{dL}$.

\section{SIMPULAN}

Dari hasil penelitian ini dapat disimpulkan bahwa sebagian besar laki-laki berusia 40-59 tahun dengan IMT $\geq 23$ $\mathrm{kg} / \mathrm{m}^{2}$ yang berdomisili di Kecamatan Malalayang memiliki kadar HDL yang normal, tetapi juga terdapat yang memiliki kadar HDL rendah.

\section{SARAN}

Laki-laki dengan IMT $\geq 23 \mathrm{~kg} / \mathrm{m}^{2}$ disarankan untuk menerapkan pola hidup yang sehat sehingga dapat terhindar dari berbagai masalah akibat berat badan lebih dan penurunan kadar HDL dalam darah yang dapat memicu terjadinya penyakitpenyakit kardiovaskular.

\section{DAFTAR PUSTAKA}

1. Gondosari AH. Kolesterol, asam lemak jenuh, dan asam lemak tak jenuh. Dalam: Wijdan FR, editor. The Miracle of 5 Elements Energy. Depok: E-tera, 2010; hal 43-50.

2. Marks DB, Marks AD, Smith CM. Metabolisme Kolesterol dan Lipoprotein Darah. Dalam: Pendit B, editor. Biokimia Kedokteran Dasar. Jakarta: EGC, 2000; hal.513-32.

3. Djohan BA. Penyakit Jantung Koroner dan Hipertensi. Medan: Universitas Sumatra Utara, 2004; hal.3- 6.

4. Tapan E. Penyakit Jantung Koroner. Dalam: Sofnir A, editor. Penyakit Degeneratif. Jakarta: Pt Elex Media Komputindo, 2005; hal.19-27.

5. Carter M. Low HDL cholesterol the biggest modifiable risk for cardiovascular disease in patients with HIV. [homepage on the Internet]. 2011 [update 2011 feb 25; cited 2012 Mar 7]. Available from: URL: http://www.aidsmap.com/Low-HDLcholesterol-the-biggest-modifiable-riskfor-cardiovascular-disease-in-patientswith-HIV updated/page/1674803/

6. UPT-Balai Informasi Teknologi LIPI. Kolesterol Tinggi. Pangan \& Kesehatan. [homepage on the Internet]. 2009 [cited 2012 Mar 20]. Available from: URL: http://id.scribd.com/doc/112060811/hyperl ipidemia

7. Patient education: Mengenal kolesterol dan dampaknya terhadap kesehatan. [homepage on the internet]. 2008 [cited 2012 jan 25]. Available from: URL: http://www.majalahfarmacia.com/rubrik/o ne news print.asp?IDNews $=1030$.

8. Penyakit Jantung Koroner. [homepage on the internet]. 2008 [cited 2012 jan 11]. Available from: URL: http://himapid.com/2008/10/penyakitkardiovaskuler-pkv-terutama.html

9. Mawi M. Indeks Massa Tubuh Sebagai Determinan Penyakit Jantung Koroner Pada Orang Dewasa Berusia diatas 35 Tahun. Jakarta: Bagian Fisiologi Fakultas Kedokteran Universitas Trisakti, 2009; hal.1-9. 